Henry Jackman

Department of Philosophy

York University, Toronto
Original Scientific Paper

UDK 165 Витгенштајн Л.

165 Џејмс В.

$81^{\prime} 37: 165$

\title{
WILLIAM JAMES ON CONCEPTIONS AND PRIVATE LANGUAGE ${ }^{1}$
}

\begin{abstract}
William James was one of the most frequently cited authors in Wittgenstein's Philosophical Investigations, but the attention paid to James's Principles of Psychology in that work is typically explained in terms of James having 'committed in a clear, exemplary manner, fundamental errors in the philosophy of mind.' (Goodman 2002, p. viii.) The most notable of these 'errors' was James's purported commitment to a conception of language as 'private'. Commentators standardly treat James as committed to a conception of language as private, and the most notorious instance of this commitment can purportedly be found in his discussion of the feelings associated with logical terms like 'and', 'if' and 'but' in the Principles's chapter, 'The Stream of Thought'. However, the received view stands in need of serious re-evaluation. In particular, there is little reason to think that James's notorious discussion of the 'if-feeling' should be understood as an attempt to give an account of the meaning of 'if' (indeed, there is little reason to even think that Wittgenstein interpreted him this way). The picture of our ideas developed in 'The Stream of Thought' sits badly with any theory that identifies meanings with ideas in this way, and while James's chapter on 'Conception' (as well as some portions of Some Problems of Philosophy) has also been portrayed as committing James to the in principle privacy of language, it will be argued here that James's account of our 'conceptions' is radically different from that of the private linguist.
\end{abstract}

\section{Introduction}

William James was one of the most frequently cited authors in Wittgenstein's Philosophical Investigations (tied with Frege and behind only Augustine), ${ }^{2}$ but while Wittgenstein was famously a fan of James's The Varieties of Religious Experience $^{3}$ this attributed fondness is rarely extended to James's Principles of

1 I'd like to thank audience members in Chicago, Birmingham, Hamilton, Las Vegas, Helsinki, and Calgary for comments on earlier versions of this paper. I'd especially like to thank Russell Goodman and the late Richard Gale, both of whom gave generous feedback on earlier drafts. I'm focusing on the differences with them in what follows, but I've learnt a tremendous amount from both. Without the former, I'd not have thought seriously about the relation between Wittgenstein and James, and without the latter, I would not have thought seriously about James at all.

2 See Goodman 2002 p. 61.

3 He wrote to Russell in 1912 'This book does me a lot of good.' (Von Wright, 1974, p. 10.) 
Psychology (hereafter 'PP'). Indeed, Wittgenstein's well-documented attention to the later book was often explained in terms of James being a classical exponent of the tradition in the philosophy of mind that [Wittgenstein] was opposing, ${ }^{4}$ and the received view of the relation between James and Wittgenstein is that 'James was important to Wittgenstein primarily because he committed in a clear, exemplary manner, fundamental errors in the philosophy of mind. 5

The most notable of these 'errors' involved James's purported commitment to a conception of language as 'private. As Richard Gale puts it in his The Divided Self of William James:

It is this commitment to an in-principle private language that earned James the distinction of being the major whipping boy of the latter Wittgenstein. One gets the feeling that Wittgenstein wrote his Philosophical Investigations with an open copy of The Principles of Psychology before him, especially the chapter of 'The Stream of Thought'. (Gale 1999, p. 165)

Gale is certainly not alone in this view, and commentators standardly treat James as committing himself to a conception of language as private in the Principles's ninth chapter, 'The Stream of Thought'.

However, the received view stands in need of serious re-evaluation, and, in this respect, the reception of Wittgenstein's work has had a largely pernicious effect on our understanding of James. In particular, the picture of our ideas developed in 'The Stream of Thought' sits badly with any theory that identifies meanings with ideas in the way that Wittgenstein targets. Further, while the Principles's twelfth chapter, 'Conception' (as well as some portions of Some Problems of Philosophy), has also been portrayed as committing James to the privacy of language, it will be argued here that James's account of our 'conceptions' is radically different from that of the private linguist, and that when James claims, for instance, that we are 'the mind can always intend, and know when it intends, to think of the Same' (PP 434), he isn't referring to any sort of epistemic achievement.

4 Coope, Geach, Potts \& White 1970, p.7. For some other instances of the received view, see Budd 1989 pp. 157-64, Fogelin 1987 pp. 176-7, Hacking 1982, Hacker 1990 (Ch. 2), 1996 (Ch. 4-6), and Hilmy 1987 p. 198. For a discussion of some of these instances of this received view, see Boncompagni, 2012, p. 37, 2016, p. 6, and Goodman 2012, p. 62.

5 Goodman 2002, p. viii. I should note that Goodman is here describing rather than endorsing the received view. Goodman is mainly concerned with pushing back against that view, and he makes a persuasive case for Wittgenstein having in many respects not only 'learned from', but also 'loved and trusted' James (Goodman 2002, pp. 179, 3). That said, when it comes to the privacy of language, even Goodman seems willing to endorse the received view (and is thus happy to assume that James 'would have been forced to acknowledge the force of Wittgenstein's criticisms of his unrelieved empiricism' (Goodman 2002, p. 179)). 


\section{The 'if feeling'}

While Wittgenstein discussed a number of topics from James's Principles, we will start here with the passages relating to what Wittgenstein refers to as the 'if-feeling of James', since perhaps the most damaging effect of reading Wittgenstein and his commentators (at least vis a vis our understanding of James) is that it can leave one with the impression that James argued that the meanings of words like 'and', 'if' and 'but' were the particular feelings that we had when we used those words.

Wittgenstein's arguments that (1) there are no such unique repeatable feelings associated with the use of a word like 'if' and (2) even if there were, they wouldn't capture the meaning of the word (P.I., Part 2, \#37-45), seem completely persuasive. Indeed, the 'if-feeling' theory of meaning for 'if' seems like such an obvious non-starter that it is easy to see why anyone who first became acquainted with James through reading about it might decide that there was no point in wading through all (or any) of the other $1200+$ pages of The Principles of Psychology. ${ }^{6}$ It is fortunate for James, then, that there is little reason to think that he was committed to anything like the 'if-feeling' theory of meaning for 'if'. In fact, it will be argued below that there is reason to doubt that Wittgenstein even attributed such a theory to James.

Now the passage that purportedly gets James into all his trouble with Wittgenstein runs as follows:

We ought to say a feeling of $a n d$, a feeling of if, a feeling of but, and a feeling of $b y$, quite as readily as we say a feeling of blue or a feeling of cold. Yet we do not: so inveterate has our habit become of recognizing the existence of substantive parts alone, that language almost refuses to lend itself to any other use. (PP 238)

One should note immediately that this passage only affirms the existence of the if-feeling, it says nothing about the feeling's having any meaning-determining role. So, why should this passage, which does not explicitly endorse the iffeeling theory, be understood as committing James to it? Even commentators who attribute the view to James have admitted that the textual evidence for the attribution is inconclusive. For instance, Goodman writes:

James does not actually say, although he suggests, that the feeling of 'and' is the meaning of the word 'and'. In any case, this is the way Wittgenstein does take it, if not in Philosophical Grammar, then in The Brown Book of 1934-5, and Part 2 of the Investigations. ${ }^{7}$

6 This was certainly the effect that it had on me as an undergraduate, and it took more than a little arm twisting on Richard Gale's part for me to put those prejudices aside long enough to actually take a graduate seminar on James' work.

7 Goodman, 2002, p. 75. For another resent interpretation of James as a justified target for Wittgenstein's private language argument, also Boncompagni 2012, p. 41. 
However, when we are dealing with a theory as manifestly implausible as the 'if-feeling' theory, we should look for more than a suggestion before we attribute it to anyone. This is especially true in James's case, since there is good reason to think that, given what else he says in the Principles, he could not have consistently endorsed such a theory.

The if-feeling-theory is, after all, a species of what could be called 'crude empiricism' about meaning and content, since it treats our words merely as labels for the 'ideas' which constitute the 'meanings' of those words. There is, say, a fixed 'blue-idea' and 'blue' is simply a label for that idea. The if-feelingtheory simply adds to the empiricist's standard stock of meaning-constitutive ideas by claiming that words like 'and', 'if' and 'but' are labels for a less salient ideas that had previously been ignored because of our 'inveterate' habit of recognizing only the 'substantive' parts of experience (PP 238).

While many have read James's claim that we ought to say a feeling of if 'quite as readily as we say a feeling of blue' as an endorsement of the if-feeling theory, the quotation only begins to suggest this if James already endorsed something like a crudely empiricist account of the meaning of 'blue'. But, as we shall see, James challenges just such accounts less than 15 pages before his putative endorsement of the if-feeling-theory.

For instance, Wittgenstein casts doubt on the claim that there is any single 'if-feeling' by asking:

Are you sure that there is a single if-feeling, and not perhaps several? Have you tried saying the word in a great variety of contexts? For example, when it bears the principal stress of the sentence, and when the word next to it does. (P.I. part 2, \#39.)

Goodman claims that 'Wittgenstein examines a variety of cases, but fails to find the feeling that James supposed must always be there' (Goodman 2002, p. 75), but Wittgenstein's suggestion that there is no single if-feeling shared across contexts would hardly have been news to James, who argues that there is no single feeling associated with 'blue' or 'cold' either. As he puts it:

[c]lose attention to the matter shows that there is no proof that the same bodily sensation is ever got by us twice... What is got twice is the same OBJECT. We hear the same note over and over again; we see the same quality of green, or smell the same objective perfume, or experience the same species of pain. The realities, concrete and abstract, physical and ideal, whose permanent existence we believe in, seem to be constantly coming up before our thought, and lead us, in our carelessness, to suppose that our 'ideas' of them are the same ideas. (PP 225)

The belief that we have such repeatable ideas is a classic example of what James calls 'the psychologist's fallacy', namely, the psychologist's 'confusion of his own standpoint with that of the mental fact about which he is making 
his report.8 This fallacy, which involves attributing to ideas properties that are only held by their objects is explicitly taken by James to ground classical empiricist psychology, and it is precisely such psychology that leads to a conception of language as private. As James puts it:

Naming our thought by its own objects, we almost all of us assume that as the objects are, so the thought must be. The thought of several distinct things can only consist of several distinct bits of thought... As each object may come and go, be forgotten and then thought of again, it is held that the thought of it has a precisely similar independence, self-identity, and mobility. The thought of the object's recurrent identity is regarded as the identity of its recurrent thought; and the perceptions of multiplicity, of coexistence, of succession, are severally conceived to be brought about only through a multiplicity, a coexistence, a succession, of perceptions. The continuous flow of the mental stream is sacrificed, and in its place an atomism, a brickbat plan of construction, is preached, for the existence of which no good introspective grounds can be brought forward...These words are meant to impeach the entire English psychology derived from Locke and Hume, and the entire German psychology derived from Herbart, so far as they both treat 'ideas' as separate subjective entities that come and go. (PP 194-195, italics mine.)

It may be possible that over the next few pages James simply forgot all of this, or somehow thought that the crudely empiricist theory worked for 'if' even though it didn't work for 'blue', but it is more plausible to think that he took it to work for neither.

On such a reading, just as James understood a set of experiences as 'cold-experiences' or 'blue-experiences' because they were associated with particular 'concrete' and 'physical' realities, he understood another set of experiences as 'and-experiences' because they were associated with particular 'abstract' and 'ideal' realities/relations. The meanings of the terms relate to

8 PP 195. He describes this fallacy in further detail in PP 268:

We have the inveterate habit, whenever we try introspectively to describe one of our thoughts, of dropping the thought as it is in itself and talking of something else. We describe the things that appear to the thought, and we describe other thoughts about those things-as if these and the original thought were the same. If, for example, the thought be 'the pack of cards is on the table, we say, "Well, isn't it a thought of the pack of cards? Isn't it of the cards as included in the pack? Isn't it of the table? And of the legs of the table as well? The table has legs-how can you think the table without virtually thinking its legs? Hasn't our thought then, all these parts-one part for the pack and another for the table? And within the pack-part a part for each card, as within the tablepart a part for each leg? And isn't each of these parts an idea? And can our thought, then, be anything but an assemblage or pack of ideas, each answering to some element of what it knows?' 
the common realities that the experiences were experiences of, not (or at least not just) the experiences themselves. ${ }^{9}$

It shouldn't be surprising that James denies that there were any such repeatable experiences to serve as the meaning of 'blue', 'cold' or 'if'. The chapter where James discusses the if-feeling is called 'The Stream of Thought' for a reason, and one of the main conclusions of that chapter is that there are no ideas of the sort associated with the crudely empiricist model of meaning. As James puts it:

There is no manifold of coexisting ideas; the notion of such a thing is a chimera. Whatever things are thought in relation are thought from the outset in a unity, in a single pulse of subjectivity, a single psychological feeling, or state of mind. (PP 268.)

What we experience are things in relations, and we typically no more have a separate experience of things than we do of the relations themselves. In light of this holism about the structure of thought, James's claim that 'We ought to say ... a feeling of if ... quite as readily as we say a feeling of blue', can be read as merely putting the two in the same group, and unless you think that the crudely empiricist account works for 'blue', it won't lead you to think that it would work for 'if'. Conversely, (and importantly for Wittgenstein), if you don't think that it will work for 'if', then you shouldn't endorse it for 'blue' either. The much-maligned 'if-feeling' passage is thus better understood in the context of the holistic claim that there is no unique (distinct/repeatable) blue-feeling than it is as the implausible suggestion that there is a unique meaning-determining feeling associated with 'if.' ${ }^{10}$

So why would Wittgenstein attribute the if-feeling theory to James? No one has ever accused Wittgenstein of being an overly generous interpreter of others, but it is not as if Wittgenstein simply remembered James's claim from hearing someone else quote it out of context. Wittgenstein was actively engaged with James's book for at least a decade (at one point the Principles made up

9 'If there be such things as feelings at all, then so surely as relations between objects exist in rerum naturâ, so surely, and more surely, do feelings exist to which these relations are known.' (PP 238, italics James's.)

10 All that said, one might still think that James commits himself to something like the empiricist theory of meaning soon after in 'The Stream of Thought' when he says that '... no word in an understood sentence comes to consciousness as a mere noise. We feel its meaning as it passes' (PP 271, italics mine). However, there is a large gap between saying that we feel a word's meaning as it passes and saying that in such cases the meaning is the passing feeling. Saying that we feel the meaning as it passes no more commits us to meanings being feelings than saying I saw the army as it passed commits me to the army being a visual impression. Those inferences would follow only if our ideas were the only things we could feel or see, but James's account of perception, both in the Principles and throughout his later work, rejects precisely the assumption that the objects of perception need be restricted in this way. 
the entirety of his philosophical library), ${ }^{11}$ and he seriously considered using James's Principles as the text for his graduate course at Cambridge, ${ }^{12}$ so it would be surprising to find that he misread James so badly. This interpretive problem disappears if it turns out that Wittgenstein didn't read James this way, and in what follows, I'll raise some doubts about whether the 'if-feeling' theory was ever really attributed to James by Wittgenstein.

James is not explicitly cited in the discussions of the if-feeling in the Investigations, and while Wittgenstein does mention James in his earlier discussion of the if-feeling in the Philosophical Grammar, those passages don't present the feeling as a candidate for the meaning of 'if', and generally don't seem critical of James at all. ${ }^{13}$ Still, while James is not explicitly mentioned in the if-feeling sections of the Investigations, he does turn up in a similar set of remarks in the Brown Book that run as follows:

We think of the meaning of signs sometimes as states of mind of the man using them, sometimes as the role which the signs are playing in a system of language. The connection between these two ideas is that the mental experiences which accompany the use of a sign undoubtedly are caused by our usage of the sign in a particular usage of language. William James speaks of specific feelings accompanying the use of such words as 'and', 'if', 'or.' And there is no doubt that at least certain gestures are often connected with such words.... And there obviously are visual and muscular sensations connected with these gestures. On the other hand it is clear enough that these sensations do not accompany every use of the word 'not' and 'and'. If in some language the word 'but' meant what 'not' means in English, it is clear that we should not compare the meaning of these two words by comparing the sensations which they produce. ... But we do not want to deny that the people who use the word 'but' as 'not' is used in English will, broadly speaking have similar sensations accompanying the word 'but' to those the English have when they use 'not'. And the world 'but' in

11 Though there may be some dispute about just what version of James's Psychology Wittgenstein was reading. Nubiola suggest that Anscombe said that Wittgenstein only read Psychology: The Briefer Course, rather than the full Principles of Psychology. (He cites Haack (1982, p. 163, n.1) as source for this (Nubiola 2000, p. 3)). On the other hand, Passmore (1957, p. 428, n. 2.) seems to suggest that the full Principles was what James was reading.

12 For a discussion of the extent of Wittgenstein's engagement with the Principles and how, see especially Goodman 2002, ch. 3 .

13 See Goodman 2002, p. 60. The passage in question reads: 'A man who reads a sentence in a familiar language experiences the different parts of speech in quite different ways. (Think of the comparison with meaning-bodies.) We quite forget that the written and spoken words for 'not', 'table' and 'green' are similar to each other. It is only in a foreign language that we see clearly the uniformity of words. (Compare William James on the feelings that correspond to words like 'not', 'but' and so on.)' (Wittgenstein 1974, 58). 
the two languages will on the whole be accompanied by different sets of experiences. (Wittgenstein 1958, 78-9)

In this quote, Wittgenstein claims that James talks about the existence of the if-feeling, but, once again, he doesn't attribute to him any commitment to its being meaning-determining.

Wittgenstein may, then, not be so much criticizing James as working with him. ${ }^{14}$ James argues in 'The Stream of Thought' that the dominant strains in both the 'empiricist' and 'intellectualist' traditions deny that there were any experiences of relations (the empiricists denying that any ideas corresponded to the words in question, while the intellectualists took such ideas to be imposed a priori on experience), and his main concern in those passages is arguing for the existence of such experiences, not for their meaningdetermining role.

The mere existence of such experiences is, however, bad news for the crude empiricist about linguistic and thought content, since the empiricist theory seems so implausible if extended to terms like 'if' and 'but'. By helping himself to James's phenomenological claim, Wittgenstein can thus present the crudely empiricist position in as poor a light as possible. Consider, for instance, the following passage from The Big Typescript:

What do we want to understand by the 'meaning' of a word? A characteristic feeling that accompanies the uttering (hearing) of the word? (James's and-feeling, if-feeling.) Or do we want to use the word 'meaning' completely differently; and say, for instance, two words have the same meaning if the same grammatical rules apply to both? (Wittgenstein 2005, p. 29)

James can be read here (and may have been read by Wittgenstein) not as offering an account of the meaning of the words in question, but as a source for the existence of a particular set of feelings for which the crudely empiricist account seems highly implausible. ${ }^{15}$

After all, Wittgenstein's question would have considerably less rhetorical force if he took his examples from the stock of cases considered by Russell, ${ }^{16}$ as the following modification of the quotation immediately above should make clear.

What do we want to understand by the 'meaning' of a word? A characteristic feeling that accompanies the uttering (hearing) of the

14 Which is, of course, how Goodman characterizes Wittgenstein's earlier treatment of this bit of James in the Philosophical Grammar (Goodman 2002, p. 60).

15 So the quote need not be, as Goodman suggests (2002, p. 76), a case where Wittgenstein 'attributes to James the idea that meanings are states of mind'.

16 See, for instance, fifth chapter of his The Problems of Philosophy (Russell 1912). 
word? (Russell's pain-feeling, white-feeling.) Or do we want to use the word 'meaning' completely differently; and say, for instance, two words have the same meaning if the same grammatical rules apply to both?

If we stick to more typical examples like 'pain' or 'white' the crudely empiricist theory does have a certain appeal, an appeal which disappears quickly when Wittgenstein helps himself to the broader palette of psychological phenomena found in James's Principles of Psychology. James's work serves as a remedy for the 'one-sided diet' of examples that can make theories like crude empiricism tempting. ${ }^{17}$ Earlier empiricists could duck these cases by suggesting that since there were no experiences associated with such words, they must pick out relations between ideas rather than ideas themselves, but once one accepts James's phenomenological claims, that line of defense becomes unavailable.

\section{Conceptions and the 'Constancy of the Mind's Meanings'}

Reading the if-feeling passages as an extension of, rather than criticism of, crude empiricism is just one symptom of the general tendency to treat James as endorsing the kind 'idea-based' theory of meaning targeted by Wittgenstein's private-language argument. ${ }^{18}$ This tendency to see James as presenting a classic version of a private language might seem strange given that, for the classic private linguist, words pick out private, repeatable ideas, which only the thinker has access to, and James seems to deny precisely that such ideas exist. Wittgenstein's criticisms of private sensation language relate to the question of how the speaker can really know whether the sensation he is applying a term to now is the same as the one he applied it to before, but for James such worries make no sense. Ideas are never repeated, so we could know whether or not our words are being prompted by the same ideas that they were before, it's just that the answer is always that they aren't, and so no notion of correctness can be based on conformity to the ideas originally attached to our words.

17 'A main cause of philosophical disease-a one-sided diet: one nourishes one's thinking with only one kind of example.' P.I. 593. (For a discussion of how Wittgenstein might have used James's 'acute sense of the variety of human experience' to keep his diet well rounded, see Goodman 2002, pp. 3, 62, 82.)

18 Goodman, for instance, argues that when James thinks about linguistic meaning, he 'sees experiences as the only candidates' (Goodman 2002, p. 75), and how this general understanding leads to his interpretation of the if-feeling passages can be seen in claims such as:

The audience for Wittgenstein's question, 'Are you sure there is a single if-feeling' is, firstly, William James; and secondly, all who agree with him that a feeling does or could constitute the meaning of a term. (Goodman 2002, p. 76)

It was obvious for James to search for meaning among the specific feelings accompanying the use of such words as 'and' and 'or'-but this obvious first step was 'the one that altogether escapes notice' (PI, 308). (Goodman 2002, p. 120.) 
One might respond to this by arguing that even if James thinks that every particular thought is different, they may still share common features, and it is the repeatable elements in those states that are being picked out as the 'private' meanings of our terms. ${ }^{19}$ However, James seems to rule out even such an 'abstractionist' fallback position when he writes:

In short, it is logically impossible that the same thing should be known as the same by two successive copies of the same thought. As a matter of fact, the thoughts by which we know that we mean the same thing are apt to be very different indeed from each other. We think the thing now in one context, now in another; now in a definite image, now in a symbol. Sometimes our sense of its identity pertains to the mere fringe, sometimes it involves the nucleus, of our thought. (PP 454)

Indeed, much of the Principles's chapter titled 'Conception' is dedicated to criticizing precisely the assumption that a general idea would require such a 'repeatable core' that would be shared by all the particular experiences of its instances. It is another version of the fallacy described earlier where 'The thought of the object's recurrent identity is regarded as the identity of its recurrent thought' (PP 194). In particular, he thinks that this assumption draws from the further assumption that for an idea to be about something external to it, it must somehow resemble that thing. As James puts it:

It is easy to lay bare the false assumption which underlies the whole discussion of the question as hitherto carried on. That assumption is that ideas, in order to know, must be cast in the exact likeness of whatever things they know, and that the only things that can be known are those which ideas can resemble. (PP 445)

By contrast, James thinks that 'All that a state of mind need do, in order to take cognizance of a reality, intend it, or be 'about' it, is to lead to a remoter state of mind which either acts upon the reality or resembles it' (PP 445). ${ }^{20}$ What is essential to our thoughts' being about various objects and properties is their eventually 'acting upon' such realities, not their resembling them. Since this 'acting upon' takes place in an external (and public) environment, there is no reason to treat the resultant meanings as 'private.' You know what I mean by 'blue' not by looking in to my mind, but by seeing which things I treat as 'blue.' My dog-ideas are all dog-ideas not because they all have some common subjective kernel, but because they are all about dogs, and James sees no reason why the latter should require the former.

That said, even generally sympathetic commentators such as Gale and Goodman assume that James must be committed to a picture of language

19 This seemed to be one line that Goodman took in his response to an earlier version of this paper (Jackman 2004).

20 For a more extended discussion of this, see Jackman 1998, forthcoming. 
as private given what other things James says in that very same chapter on 'Conception'. Nevertheless, I'll argue in what follows that the relevant passages from the chapter on conception are better read as presenting a view very different from the one Goodman and Gale assume that James is endorsing.

Before discussing James's position in that twelfth chapter, it may be worth making a few remarks about James's use of the word 'conception', since it is importantly different from the usage most familiar from contemporary philosophical discussion. Philosophers typically distinguish concepts from conceptions in terms of concepts being objective and public and conceptions being private and subjective, so that while we all may share the same water concept, our conceptions of water are all different (and changing all the time as well). If conceptions are understood this way, tying meanings to conceptions would push one towards a picture of language as private, so it is important to stress that this is not the way that James understands conceptions here. Rather, James thinks of conceptions in terms of neither objects in the world, nor mental states, but rather in terms of the relations between them. As he puts it:

The function by which we thus identify a numerically distinct and permanent subject of discourse is called CONCEPTION; ...The word 'conception' is unambiguous. It properly denotes neither the mental state nor what the mental state signifies, but the relation between the two, namely, the function of the mental state in signifying just that particular thing. (PP 436) 21

Since conception is 'the function by which a state of mind means to think the same whereof it thought on a former occasion', two states of mind will 'be two editions of the same conception just so far as either does mean to think what the other thought; but no farther' (PP 442). ${ }^{22}$

It is precisely this purported phenomenon of one state of mind 'meaning to think what another one does' that Gale thinks pushes James towards a

21 James then (to contemporary ears somewhat perversely) goes on to take 'Concept' to more properly pick out the subjective state: 'the thoughts which are [a conception's] vehicles are called concepts' (PP 436). He recognizes that 'the word 'concept' is often used as if it stood for the object of discourse itself' and concludes that 'this looseness feeds such evasiveness in discussion that I shall avoid the use of the expression concept altogether, and speak of 'conceiving state of mind' or something similar, instead.' (PP 436). Later on in the Principles, in the chapter on "The Perception of "Things"' (PP, Ch. 19), James reverts to more familiar terminology, stressing 'the difference between our psychological conceptions and what are called concepts in logic. In logic a concept is unalterable; but what are popularly called our 'conceptions of things' alter by being used' (PP 753). James sticks with this later terminology in subsequent writings such as the discussion of Precepts and Concepts in Some Problems of Philosophy.

22 Note that this will allow James to tie conceptions to their extensions while still being able to insist that, say, 'hesperus' and 'phosphorus' are tied to different conceptions, since, even if they, in fact, pick out the same object, they are not intended by the speakers to do so. In more contemporary terms, 'anaphoric' co-reference types conceptions, mere coreference isn't enough. 
conception of language as private. For instance, James states that we are able to form general conceptions, because of:

A fundamental psychical peculiarity which may be entitled 'the principle of constancy in the mind's meanings', and which may be thus expressed: 'The same matters can be thought of in successive portions of the mental stream, and some of these portions can know that they mean the same matters which the other portions meant. One might put it otherwise by saying that 'the mind can always intend, and know when it intends, to think of the Same.' (PP 434, italics James's)

This 'peculiarity' is later framed as the fact that 'we can at any moment think of the same thing which at any former moment we thought of', and this 'ultimate law of our intellectual constitution' (PP 920) can easily be understood in a way that quickly makes James seem like a private linguist. ${ }^{23}$

Gale is certainly right to think that 'the principle of constancy in the mind's meanings' plays an important role for James, but he gives it an unjustifiably 'epistemic' reading. In particular, Gale takes a principle of James's which is about our authority about the commitments we take on, and changes it into a principle about our authority about whether those commitments have been satisfied.

This principle or law is of a subjective character, as it is the subject's 'intention ... to think of the same', about which he cannot be mistaken, that determines the extension of his general concept over time (PP 435). 'Each thought decides, by its own authority', whether it's present content is an instance of what it formerly intended to count as an instance of the same concept. (Gale 1999, p. 164)

Gale concludes from this ${ }^{24}$ that, for James, 'each subject follows an inprinciple private rule in determining which individuals count as instances of a given general concept. He and he alone knows whether he is following his intentions to call these experiences instances of this concept' (Gale 1999, p. 164).

Gale then argues that James's so-called commitment to the privacy of language finds an even clearer expression in James's final work, Some Problems of Philosophy. In that book, James claims that with a general term like, say, 'white', we can gather together into its extension instances of white that differ in their experienced color, provided that 'we mean that our word shall unalterably signify' a color common to them all (Gale 1999, p. 164). The

23 Goodman agrees with Gale that 'James embraces a key component of the private language position in the 'Conception' chapter of The Principles', and that this key component is the assumption that 'I have the power to determine a thought as 'the same thought.' (Goodman 2002, pp. 105, 109.).

24 Indeed, the link between what follows and the quotation immediately above is simply 'In other words.... 
passage Gale quotes from immediately above, and goes on to quote at greater length, runs as follows:

[W]e know that under all modifications wrought by changing light, dirt, impurity in pigment, etc., there is an element of color-quality, different from other color-qualities, which we mean that our word shall inalterably signify. The impossibility of isolating and fixing this quality physically is irrelevant, so long as we can isolate and fix it mentally, and decide that whenever we say 'white' that identical quality, whether applied rightly or wrongly, is what we shall be held to mean. Our meanings can be the same as long as we intend to have them so. (SPP 57)

Gale then pushes James's discussion of the possibility of error suggested in the passage above (the admission that the term can be applied 'rightly or wrongly') in a surprising direction, effectively doubling down on his 'epistemic' reading of our ability to 'think the same' by insisting:

James does allow for the possibility of the speaker 'rightly or wrongly' applying 'white', but only the speaker is able to determine whether he is correctly adhering to his own private rule. The reason is that his paradigm of whiteness, which is a mental image private to himself, is not in principle accessible to anyone else. It is Wittgenstein's beetle in the matchbox that is observable only by the matchboxe's owner. Therefore no one else can check up on the speaker to determine whether he is consistently adhering to his rule always to call things white that have the same color as his mental paradigm of whiteness. (Gale 165, italics mine)

Given what we've seen before, it's hard to see how we could expect James to think that the meaning of 'white' could be determined by some private 'mental paradigm of whiteness. If our mental states are taken to be unrepeatable, there would be no way for the subject to access this 'mental image private to himself' meant to serve as a stable qualitative paradigm for the term that would allow him to 'adhere to his own private intention always to call things 'white' that have the same color as the specimen he has mentally isolated and officially dubbed as the standard of whiteness' (Gale 164-165).

In light of these problems, I would argue that the passages above are better read as relating to the subject's ability to decide that he means the same thing by 'white' today as he did yesterday, than it is as claiming that the subject has the ability to tell whether a currently confronted sample (correctly) falls under his concept of 'white. That one could have such authority about the commitments one takes on isn't that surprising, and deciding that one means by a term what one did yesterday doesn't require any particular epistemic 
achievement unless you are already committed to something like crude empiricism about the content of our thoughts. When I say:

John went to the store. He was planning to buy a bag of nails.

I can know that 'John' and 'He' pick out the same person simply because I intend them too, the reference of 'he' in this case is structurally (or in more contemporary terms, anaphorically - in the broad 'discourse anaphora' sense), dependent on the referent of 'John' and doesn't have its reference determined independently. ${ }^{25}$ In much the same way, if I say.

John never liked Peter. I'm not sure why, but it's probably because he is such a snob.

I can decide whether 'he' refers to John or Peter, and this isn't because I'm particularly good at inspecting the idea associated with 'he' and recognizing that it matches the idea associated with, say, 'Peter.' ${ }^{26}$ The connection is structurally/anaphorically rather than epistemically determined.

Talking of these connections as 'anaphoric' is perhaps a somewhat anachronistic way of putting the point, but it serves to highlight that James

25 Of course, the two sentences could be uttered in a context where ' $\mathrm{He}$ ' was used demonstratively and I just happened to think that John was the person being demonstrated, but the existence of such contexts doesn't take away from the relevance of the more typical cases where the co-reference is determined anaphorically.

26 Goodman takes issue with James's claim that:

Each thought decides, by its own authority, which, out of all the conceptive functions open to it, it shall now renew; with which other thought it shall identify itself as a conceiver, and just how far. 'The same A which I once meant', it says, 'I shall now mean again, and mean it with $\mathrm{C}$ as its predicate (or what not) instead of $\mathrm{B}$, as before' (PP, 442 n. 6).

According to Goodman,

Each thought at a moment has the 'authority', James is saying, to constitute meaning, and it can do so apart from 'everything else in the world': 'Conceptualism says the mind can conceive any quality or relation it pleases, and mean nothing but it, in isolation from everything else in the world. This is, of course, the doctrine we have professed' (PP, 444). Because of his tendency to treat both meaning and the self from 'an exclusively first-person perspective' James may thus have been one of Wittgenstein's targets in his discussions of a private language, although Wittgenstein does not cite the passages previously mentioned either in the Investigations or in his Notebooks. (Goodman 2002, pp. 105-106)

Goodman here seems to be assuming that the phrase 'in isolation from everything else in the world' entails that James is saying that our meaning-constituting activities can take place 'in isolation' (so that it would be some pure mental act that requires no physical context). I'd argue instead that he is suggesting that the meanings constituted pick out particular properties 'in isolation' from everything else, so, say the concept of triangle picks out the shape in isolation from the colors, textures, and other properties that particular triangles may have. (This sense that concepts "exclude" all but their chosen aspect of the material they conceptualize is a running theme throughout James's work.) 
does explicitly describe this sameness as a function of the mind's structure rather than, say the phenomenal content of the ideas passing through it.

Note, however, that we are, in the first instance speaking of the sense of sameness from the point of view of the mind's structure alone, and not from the point of view of the universe. We are psychologizing, not philosophizing. That is, we [we psychologists, not we thinkers in general] do not care whether there be any real sameness in things or not, or whether the mind be true or false in its assumptions of it. Our principle only lays it down that the mind makes continual use of the notion of sameness, and if deprived of it, would have a different structure from what it has. In a word, the principle that the mind can mean the Same is true of its meanings, but not necessarily of aught besides. (PP 435, italics James's, boldface mine.)

Note that his denial that there must be any 'real sameness' applies just as much to our ideas as to objects in the world, and for the mind to be structured so that items are recognized as the same, it doesn't need to have ideas which are themselves identical. That said, while 'the law of constancy in our meaning' is 'the most important of all the features of our mental structure' (PP. 435), James isn't really full of details about just how these structural connections work, insisting instead that:

Introspective psychology must here throw up the sponge; the fluctuations of subjective life are too exquisite to be arrested by its coarse means. It must confine itself to bearing witness to the fact that all sorts of different subjective states do form the vehicle by which the same is known; and it must contradict the opposite view. (PP 454)

This sort of structural connection is, of course, not limited to proper names and pronouns, and James makes the same sort of point about general terms like 'white.' What we are doing is not making the epistemic determination that a set of ideas are identical, but rather making the stipulation that a set of non-identical ideas are intended to pick out the same object or property. I can mean $d o g$ by 'dog' because (as we saw earlier) I can take all of the instances of 'dog' that I use to mean the same thing. However, my meaning the same thing by 'dog' as I meant yesterday is not some sort of epistemic achievement. It is not as if I need to inspect my dog-idea and remember yesterday's dog-idea reliably enough for me to judge that they are identical.

On such a reading, just because we can always intend to apply to a particular experience the same concept that we applied to another earlier experience, it does not follow that we need be correct in doing so (in either 
case). ${ }^{27}$ Quite the contrary, one might argue that it is precisely this doctrine that lets James account for error in a way that a traditional empiricist might not be able to. For instance, when I sincerely claim

(W) The piece of paper in front of me is white.

James can claim that my concept of 'white' is determined by me to be identical to the concept I applied last month, even if I can't remember precisely what experiences I had back then. Indeed, someone who has better access to what I had applied the term to before might be better able to judge whether or not (W) was correct than I am. Without this ability to stipulate constancy of meaning, such mistakes would seem hard to explain. If I sincerely asserted (W), and what I meant by 'white' at the time were limited to what I could either call up in memory or perceive in front of me, then a crucial standard against which current use is judged, past use, would drop out.

James's 'principle of constancy' does not require that we can somehow inspect past ideas and recreate them within our current thoughts unchanged. Quite the opposite. Since, the constancy is more structural than resemblance driven, the claim that what a speaker means by 'white' is 'is a mental image private to himself' (Gale 1999, p. 165) has no real support from these passages from James. Such support would only come if one thought that constancy required the ability to pull up an identical (or at least extremely similar) experience in memory, and there is no reason to believe that James thought anything like this. ${ }^{28}$

James is instead better read as suggesting that what a word like 'white' is intended to pick out is not some private mental image, but rather the property that we presume that all/most of the things that we call white have in common. We may not know just what that shared quality is, but that doesn't prevent us from intending to pick out the shared property behind the occasions of the term's use. ${ }^{29}$ When James says:

27 In fact, James's claim "Our meanings can be the same as long as we intend to have them so, quite irrespective of whether what is meant be a physical possibility or not" (SPP 57), suggests that for some terms every particular application of the concept to external objects might be mistaken (this last point does a lot of work in the Principles's $28^{\text {th }}$ chapter on necessary truth).

28 As mentioned earlier, James doubts about the repeatability of ideas would suggest just the opposite, and while the chapters of the Principles can often be somewhat disconnected from each other (a function of both its length, James's style, and the 12 years spent in its composition), James explicitly calls back to this aspect of the "The Stream of Thought" in his chapter on conception, reminding us that "nothing can be conceived twice over without being conceived in entirely different states of mind" (PP 453, italics James's).

29 Note that James's view is presented here in the context of his rejecting that 'nominalistic' view that 'white' just picks out the property being called 'white' (SPP 56-57). 
The impossibility of isolating and fixing this quality physically is irrelevant, so long as we can isolate and fix it mentally, and decide that whenever we say 'white' that identical quality, whether applied rightly or wrongly, is what we shall be held to mean. (SPP 57).

$\mathrm{He}$ is not saying, in the absence of discovering the precise physical property that all the things we call 'white' share, we focus instead on some qualitative mental property that we take to be the meaning of the term. Rather, he is saying that we can pick out the shared property by the intention to refer to the property, whatever it is, that the structurally/anaphorically linked uses of the term have in common. ${ }^{30}$

This may be less obvious with 'white' where the mentalistic understanding of the term's meaning might be tempting, but James is making a general point about our concepts in this section, not just our phenomenal ones, and James's point seems clearer with a term such as 'water', in which case the passage would read:

The impossibility of isolating and fixing this property physically is irrelevant, so long as we can isolate and fix it mentally, and decide that whenever we say 'water' that identical property, whether applied rightly or wrongly, is what we shall be held to mean. Our meanings can be the same as long as we intend to have them so.

Even if we don't know just how the property is specified (ie: we can't 'fix it physically') we can have a general intention to pick the underlying property out. James's claim that "White" means a colour-quality which the mind creates (following no matter what cue) and which it can decree to be there under all physical disguises' (SPP 57, italics mine) is about positing an underlying property that the term picks out, a property which we could be wrong in attributing in individual instances. Once again, while error is explicitly allowed for here, it would not seem to be possible on the nominalist view (where white is just the property of being called 'white') that James is criticizing in those pages.

In short, James's discussion of concepts/conceptions in the Principles's chapter on conception and in Some Problems of Philosophy fails to supports the contention that he understood meaning in a way that would have run afoul of the private language argument, since there is no suggestion in either that he thinks that we can always re-identify our ideas in terms of their phenomenal properties.

30 Such chains of anaphorically linked ideas are crucial for James's account of singular reference as well. James, claims, for instance, that our idea of Memorial Hall refers to Memorial Hall because if asked to find Memorial Hall, I could go to Cambridge and identify the correct building. However, the ability of the perception to determine the reference of a concept entertained weeks, months, or even years before depends on the existence of such anaphoric links. (Needless to say, 'anaphoric' is not the way James describes such links.) (See Jackman 1998, forthcoming.) 


\section{Conclusion}

There remain, of course, serious differences between Wittgenstein and James, ${ }^{31}$ but (whether Wittgenstein really appreciated this or not) the question of whether meaning should be understood as 'private' is not one of them. The perceived distance between Wittgenstein and the (other) Pragmatists has certainly contracted over the years, ${ }^{32}$ and seeing how one of Pragmatism's founders was not committed to one of Wittgenstein's particular bête noires should hopefully close that gap further.

\section{References}

Boncompagni, A. 2012, 'Streams and River-Beds. James' Stream of Thought in Wittgenstein's Manuscripts 165 and 129', European Journal of Pragmatism and American Philosophy, 2012, IV, 2.

Boncompagni, A. 2016. Wittgenstein and Pragmatism, London: Palgrave Macmillan.

Budd, M. 1989. Wittgenstein's Philosophy of Psychology. London: Routledge.

Coope, C., Geach, P., Potts, T., \& White, R., 1970, A Wittgenstein Workbook, Oxford: Blackwell.

Fogelin, R.J. 1987. Wittgenstein (2nd ed). New York and London: Routledge.

Gale, R 1999, The Divided Self of William James, New York: Cambridge University Press.

Goodman, R. 2002. Wittgenstein and William James. New York: Cambridge University Press.

Haack, R. 1982. 'Wittgenstein's Pragmatism', American Philosophical Quarterly, Vol. 19, No. 2. (Apr., 1982), pp. 163-171.

Hacker, P.M.S. 1990. Wittgenstein: Meaning and Mind. Oxford: Blackwell.

Hacker, P.M.S. 1996. Wittgenstein: Mind and Will. Oxford: Blackwell.

Hacking, I. 1982. 'Wittgenstein the Psychologist', The New York Review, April $1,1982$.

31 Though some of these others are often exaggerated as well. For instance, James's discussion of the deaf-mute Ballard and the possibility of 'thought without language' is typically presented by Wittgensteinians as focusing on the question of whether a creature entirely without language could engage in thought (see for instance, Goodman 2002, p. 127), while James's actual texts seems more focused on the question of whether there could be particular thoughts that were not linguistically represented by the thinker, who may or may not express some of their other thoughts in language.

32 See, for instance, Rorty 1979, Putnam 1995 (esp. ch. 2, 'Was Wittgenstein a Pragmatist?'), Goodman 2002, and more recently Boncompagni 2016 and Misak 2016. 
Hilmy, S. 1987. The Later Wittgenstein: The emergence of a New Philosophical Method. Oxford: Blackwell. P. 198.

Jackman, H. 1998. 'James' Pragmatic Account of Intentionality and Truth', Transactions of the C.S Peirce Society Winter 1998, Vol. XXXIV, No. 1.

Jackman, H. 2004. 'Russell Goodman's Wittgenstein and William James' presented to the Society for the Advancement of American Philosophy at the APA Central Division Meeting, Chicago IL, April 2004.

Jackman, H. forthcoming. 'James, Intentionality and Analysis' in Klein, (ed.) The Oxford Handbook of William James. New York: Oxford University Press, forthcoming.

James, W. 1890, 1981, The Principles of Psychology [=PP], Cambridge: Harvard University Press.

James, W. 1909. 1975, The Meaning of Truth, Cambridge: Harvard University Press.

James, W. 1911, 1979, Some Problems of Philosophy[=SPP], Cambridge: Harvard University Press.

Misak, C. 2016. Cambridge Pragmatism. New York: Oxford University Press.

Nubiola J. 2000. 'Ludwig Wittgenstein and William James', Streams of William James, 2 (3).

Passmore, J. 1957. A Hundred Years of Philosophy, New York: Macmillan.

Putnam, H. 1995. Pragmatism: An Open Question. Oxford: Blackwell.

Rorty, R. 1979. Philosophy and the Mirror of Nature. Princeton: Princeton University Press.

Russell, B. 1912, 1997. The Problems of Philosophy. New York: Oxford University Press.

Von Wright, G.H. 1974. Letters to Russell, Keynes and Moore, Oxford: Blackwell.

Wittgenstein, L. 1953. Philosophical Investigations [=P.I], third edition. Oxford: Blackwell.

Wittgenstein, L. 1958, The Blue and Brown Books ( $2^{\text {nd }}$ ed.), New York, Harper and Brothers

Wittgenstein, L. 1974. Philosophical Grammar, Berkeley: University of California Press.

Wittgenstein, L. 1988. Wittgenstein's Lectures on Philosophical Psychology 1946-47, Geach (ed) Chicago: University of Chicago Press.

Wittgenstein, L. 2005. The Big Typescript, TS 213. Oxford: Blackwell 